\title{
A férfiak férfimeddőséggel kapcsolatos ismeretei és a támogatás lehetőségei: kockázati tényezők és egyéni válaszreakciók
}

\author{
Szatmári Angelika ${ }^{1,2}$ - Fejes Zsuzsanna dr. ${ }^{3,4}$ - Király István dr. ${ }^{2}$ \\ Szegedi Tudományegyetem, ${ }^{1}$ Egészségtudományi és Szociális Képzési Kar, \\ ${ }^{2}$ Általános Orvostudományi Kar, Urológiai Klinika, \\ ${ }^{3}$ Általános Orvostudományi Kar, Magatartástudományi Intézet, Szeged \\ ${ }^{4}$ Affidea Diagnosztika Kft. szegedi telephelye, Szeged
}

\begin{abstract}
A férfimeddőség előfordulása az elmúlt évtizedekben mind világviszonylatban, mint pedig hazánkban folyamatosan növekedett és egyre inkább a középpontba került. A meddőség a reproduktív korú férfiak millióit érinti. Az ismert organikus okokon túl feltételezhetően számos életviteli és környezeti tényező is hozzájárul ehhez. A meddőség biopszichoszociális elméleti modellje lehetőséget ad arra, hogy a nemzőképesség hiányát ne csak orvosi szempontból, fiziológiai problémaként értelmezzük, hanem pszichoszociális jelenségként is. A férfiak megküzdési stratégiái, információkeresési szokásai és a meddőséggel kapcsolatos ismeretei a nókéhez hasonlóak ugyan, de a problémára adott válaszreakcióik több ponton is eltérnek. A férfimeddőség ellátásában kiemelt szerepet kell biztosítani az egészségügyi ellátók - ápolók, reproduktív orvoslás, mentálhigiénés szakemberek - által nyújtott betegvezetésnek és paramedikális tanácsadásnak mint támogató terápiának. A kezelés időszakában - az információk nyújtása mellett - az egyéni támogatás hozzájárul a keletkező hatások, tapasztalatok, ismeretek feldolgozásához, továbbá a stresszel való adaptív megküzdési stratégiák kialakításához, valamint a reproduktivitást befolyásoló egészségmagatartás-változók közvetlen vagy közvetett módosításához.
\end{abstract}

Orv Hetil. 2018; 159(31): 1262-1268.

Kulcsszavak: férfimeddőség, betegvezetés, paramedikális tanácsadás

\section{Men's knowledge of male infertility and the possibilities for supporting therapy: risk factors and individual responses}

In recent decades, the incidence of male infertility has been increasing continuously both worldwide and in Hungary and is becoming a more and more central issue. Millions of men at the reproductive age are affected by male infertility. In addition to the known organic reasons, many life-style and environmental factors can be expected to contribute to this. The biopsychosocial theoretical model of infertility allows us to interpret the lack of fertility not only from the medical point of view, but also as a psychosocial phenomenon. Men's coping strategies, health information seeking habits, and knowledge of infertility are similar to women's, but there are several different points in their responses given to the problem. So medical, nursing and other health professionals dealing with infertile male patients should devote special and high attention to patients' conducting and paramedical counselling as supportive therapy. Within the framework of this - besides giving information - the individual support contributes to the elaboration of information, arising effects and experiences, furthermore to the developement of adaptive coping strategies for stress, and to the modification of direct or indirect changes in health behavior affecting reproductive health during the treatment period.

Keywords: male infertility, patient conducting, paramedical counselling

Szatmári A, Fejes Zs, Király I. [Men's knowledge of male infertility and the possibilities for supporting therapy: risk factors and individual responses]. Orv Hetil. 2018; 159(31): 1262-1268.

(Beérkezett: 2018. március 21.; elfogadva: 2018. április 17.) 


\section{Rövidítések}

$\mathrm{BMI}=($ body mass index $)$ testtömegindex IVF $=$ in vitro fertilizáció; $\mathrm{WHO}=$ (World Health Organization) Egészségügyi Világszervezet

\section{Férfimeddőség}

A fejlett országokban a párok megközelítőleg 15-20\%-a szembesül az infertilitás problémakörével [1]. Európai adatok szerint folyamatosan emelkedik azoknak a pároknak a száma, amelyek meddőségi kezelésben részesülnek, és ez a tendencia hazánkban is megfigyelhető [2]. Magyarországon az önkéntelenül gyermektelen párok arányát $24 \%$-ra becsülik, minden negyedik pár meddőségi problémával küzd [3].

Az Európai Urológus Társaság (European Association of Urology) 2017. évi férfimeddőségi szakmai irányelvei szerint a korszerú kórismézés és terápia hatására a gyermektelen nők aránya 3\% lett, azon nők aránya pedig, akik nem tudnak annyi gyermeket szülni, mint ahányat szeretnének, végeredményben 6\% [4]. A kumulatív terhességi arány 27\%, 2 éves követéssel, azon meddő párok esetében, akiknél a meddőség elsődleges oka oligozoospermia. A nők életkora az egyetlen olyan legfontosabb változó, amely befolyásolja az eredményt az asszisztált reprodukcióban. Összehasonlítva a 25 éves nóket a 35 évesekkel, a termékenységi potenciál 50\%-ra, 38 évesen 25\%-ra és 40 éves kor felett kevesebb, mint 5\%-ra csökken. Ismert, hogy a nők számos nyugati országban elhalasztják első terhességüket az oktatásuk befejezéséig és karrierjük megkezdéséig [4].

Mivel az utódnemzés mind egyéni, mind társadalmi szempontból kulcsfontosságú, az ezen a téren tapasztalt nehézség komoly pszichés terhet róhat a meddő pár mindkét tagjára $[5,6]$. Az identitás fontos része a reprodukcióra való képesség, ezért a páciensek a meddőség megélését addigi életük legnagyobb mértékű stresszel járó eseményének tartják. Sok pár esetében meddőségük a mindennapok középpontjává válik, gyakran az élet más fontos szempontjainak kizárásával. A reprodukció feletti kontrollvesztés nagy kihívást, nehézséget jelent az érintettek számára. Az önkéntelen gyermektelenség megtapasztalásával fokozódik a szorongás, a depresszió előfordulása, ezzel párhuzamosan romlik az életminőség érzése $[7,8]$.

A meddőség definíciójának több megközelítése (biomedikális, pszichoszociális) létezik, legtöbbjük a meddőséget orvosi szempontból és a női test, a terhesség létre nem jöttének szemszögéből vizsgálja [9]. A WHO definícióját kisebb módosításokkal több mint egy évtizede fogadták el, mely szerint „a meddőség a reproduktív rendszer betegsége, mikor a terhesség 12 hónap rendszeres védekezés nélküli szexuális együttlét ellenére sem jön létre".

$\mathrm{Az}$ infertilitás leggyakoribb és egyértelmű organikus oka a női oldal esetében a petevezeték lezártsága [10]. $\mathrm{Az}$ infertilis párok esetében a vizsgálatok azt mutatják, hogy $50 \%$-ban csak a férfi partner vagy a férfi partner is érintett a meddőség kialakulásában [4].

Az andrológia a férfiinfertilitás számos különböző etiológiai faktorát tárta már fel. Míg korábban a megtermékenyítőképesség zavarát egyértelmüen hormonális problémákkal magyarázták, ma már tudjuk, hogy endokrinológiai tényezőkre a férfimeddőség eseteinek csak kis hányada vezethető vissza. A lehetséges okok között szerepelhetnek még a nemi szervek alaki eltérései (például sorvadt vagy kis méretű herék), a herék helyzeti eltérései (például hereleszállási zavarok), here-visszértágulat (varicokele), ondóúti elzáródások, gyulladások, infekciók, hormonális, genetikai, immunológiai, biokémiai kórokok, rendszerbetegségek, daganatos betegségek és azok kezelései, valamint egyéb külső károsító tényezők (például tartós hő, vibrációs ártalom stb.) hatásai is [11]. A rosszindulatú daganatos betegségek mútétes, sugár-, kemo- és biológiai kezelése káros hatással lehet a fiatal betegek későbbi fertilitási képességeire. A javuló gyógyulási esélyek mellett egyre nagyobb hangsúlyt kap a betegek hosszú távú életminősége, így a túlélésen túl jövőbeli fertilitásuk megőrzése [12].

A fenti problémák kizárása után is gyakran mutatkozik eltérés az egyes spermaparaméterek (spermiumkoncentráció és -mozgás, morfológiai jellemzők) tekintetében, ám ezek oki háttere még nem teljesen tisztázott; a környezetszennyezés kapcsán az endokrin disruptorok, valamint a relatív oxigén-szabadgyökök szerepét is feltételezik.

Az Európai Urológus Társaság 2017. évi férfimeddőségi irányelvei szerint az ismeretlen eredetű (idiopátiás) meddőség az összes eset 31\%-át teszi ki [4]. Az ismeretlen kóreredetű meddőség kialakulásában és fennmaradásában a korábbi évtizedekben jelentős szerepet tulajdonítottak az egyén és/vagy a pár pszichopatológiájának, ezáltal összevonva a pszichogén és az ismeretlen eredetű infertilitást. Az 1950-es években, amikor még a pszichopatológiai szemlélet volt az uralkodó, az esetek nagyjából $50 \%$-ára nem tudott az orvostudomány érvényes magyarázatot adni, és ez a pszichológiai faktorok szerepének túlhangsúlyozásához vezetett; a koncepció nagyjából az 1980-as évekig egyeduralkodó maradt. Az 1990-es évektól a bizonyítékokon alapuló orvoslás hangsúlyozza, hogy az ismeretlen eredetú infertilitás és a pszichogén meddőség közé nem tehető egyenlőségjel. Napjainkban a legtöbb kutató elutasítja a pszichoszociális faktorok kizárólagos szerepét a meddőség patogenezisében, de elfogadja a lelki tényezők jelentőségét a fertilitási problémák kialakulásában, fennmaradásában, illetve a meddőségi kezelés eredményességében. Az infertilitás biopszichoszociális elméleti modellje tehát lehetőséget ad arra, hogy a meddőséget ne csak orvosi szempontból, fiziológiai problémaként értelmezzük, hanem pszichoszociális jelenségként is, valamint a pszichés tényezők potenciális szerepét a kezeléseknél, a betegség alakulásában is figyelembe vegyük [13].

Ismert a férfieredetű meddőség kifejezett hatása a férfi lelkiállapotára, így depressziós és szorongásos tüneteinek fokozódására $[6,14]$. 
A férfiak jelentős distresszt tapasztalhatnak, amikor szembesülnek a meddőséggel, és valószínúleg a szorongás, a csökkent önértékelés és a társadalmi megbélyegzettség érzése erősebb a férfifaktoros meddőségben, mint az ismeretlen eredetű vagy női faktorú meddőség esetében [15]. A férfiasság és az emberi reprodukció biológiai és kulturális antropológiai elméletének áttekintői ugyancsak arra a következtetésre jutottak, hogy a meddőség potenciálisan megalázó a férfiakra, ami kedvezőtlen hatással van a férfiasságra, és stigmatizálóbb, mint a nők számára. Feltehetőleg azért, mert a férfiak képesek összeolvasztani a meddőséget, a virilitást és a szexuális teljesítményt, ami a személyes elégtelenség érzékeléséhez vezethet [16]. Ezek a tapasztalatok arra hívják fel a figyelmet, hogy az ellátás során a férfiak támogatása is szükséges, valamint érzékeny és egyedi megközelítésre van szükség.

\section{Életmód és egészségmagatartás}

A férfiak egészségi állapotáról - feltehetőleg a társadalom beállítottsága miatt - kevesebb szó esik hazánkban, mint a nőkéről. A magyar férfiak körében magas a 49 és 65 éves kor között bekövetkező, idő előtti halálozás, aminek hátterében az átalakuló társadalom krónikusstresszforrásai és a stressz levezetésére szolgáló rizikómagatartások állnak [17]. A meddőség a WHO legfrissebb definíciója alapján - orvosi megközelítés szerint - betegségnek számít, így a párok orvosi ellátásra jogosultak [18]. A betegstatust azonban a páciensek nagy része rosszul éli meg, hiszen itt lényegében egészséges férfiakról és nőkrőll van szó.

Az utóbbi évtizedekben hangsúlyossá vált az életmódváltozók mint kockázati tényezók hatása a reproduktív egészségre. A növekvő tudományos érdeklődés oka feltehetőleg abban keresendő, hogy az életmódváltozók döntően a személy kontrollja alatt álló és többé-kevésbé módosítható tényezők közé sorolhatók.

A termékenységi mutatókat kedvezőtlenül befolyásolja az obesitas azzal, hogy az spermaminőség romlását (spermiumkoncentráció és -motilitás csökkenése) okozza. Az átlagosnál nagyobb testtömeg az erectilis diszfunkció vezető kockázati tényezője [19]. A túlsúlyos férfiak esetében a nemi hormonprofil megváltozása (csökkent androgénértékek magas ösztrogénszint mellett) a spermatogenezis romlásával járhat együtt [20, 21].

Sallmén és mtsai (2006) azt vizsgálták, hogy a testtömeg milyen módon hat a fertilitásra. 2011 pár vizsgálata alapján azt találták, hogy a meddőség aránya nagyobb a férfiak azon csoportjában, amelyben a testtömegindex (body mass index, BMI) is nagyobb. A 20 és 22 közötti BMI-indexû férfiak csoportjához képest már háromegységnyi emelkedés is jelentősen megnövelte a meddőség kockázatát [22]. A túlsúlyosság hatását vizsgáló tanulmányok szerint a testtömegcsökkenés pozitívan hat a spermaanalízis mutatóira: a spermiumkoncentráció, vala- mint a normál morfológiájú spermiumok arányának szignifikáns mértékú növekedésével jár együtt [23].

A testsúly természetesen nem független a táplálkozási szokásoktól. Az erre vonatkozó kutatási eredmények szerint szénhidrátokban, rostokban gazdag étrend, megfelelően magas folsav-, likopin- és C-vitamin-szint és kisebb mennyiségű fehérje- és zsírbevitel jellemezte a normálspermaképet mutató férfiak csoportját a csökkent spermaminőségú csoporthoz képest. Feltehetőleg az alacsony antioxidánsbevitel gyakorol negatív hatást az ismert spermaparaméterekre [24].

A dohányzás többek között a szív- és érrendszeri betegségek kockázati tényezője, ugyanakkor az infertilitás tekintetében is rizikófaktornak számít. A dohányzás negatívan hat a spermaminőségre - a koncentráció-, a motilitási és a morfológiai mutatók tekintetében - az egészséges és a meddő férfiak esetében egyaránt [25]. A tesztoszteronszint csökken, növekszik az erectilis diszfunkció kialakulásának veszélye, és sok esetben romlanak a spermaparaméterek [26].

A rizikómagatartások közül a dohányzás mellett kiemelendő az alkoholfogyasztás - mindkettő szintén negatívan befolyásolja a férfiak termékenységét.

Az alkohol szignifikánsan csökkenti az ejaculatum mennyiségét, és a minőségi mutatókra (motilitás, morfológia) is negatívan hat. Egy 100 fős mintán végzett vizsgálatban a mérsékelten ivók 63\%-ánál és a nagyivók 72\%ánál a hímivarsejtek alaki, morfológiai károsodását (teratozoospermia), 54\%, illetve 64\% esetében csökkent spermiumszámot mutattak ki [25].

A testmozgás egészségvédő hatása a termékenység kapcsán is megmutatkozik. Egészséges férfiak esetében a hetente legalább háromszor egy óra sportolás kedvező hatást gyakorol a spermaminőségre, főként a morfológiai mutatókra [27]. A mértékletes testmozgás közvetett hatásai révén is kedvezően hat a termékenységre.

A túlzott gyakoriságú és intenzitású testmozgás hatása azonban már nem ilyen kedvező. In vitro fertilizációban (IVF) részt vevő férfiak közül azoknál, akik hetente öt vagy több órát kerékpároztak, alacsonyabb spermiumkoncentrációt mértek, mint a hasonló mozgásformát nem folytatóknál [28].

\section{A férfimeddőségre adott reakciók aspektusai}

A gyermekvállalás fontos kérdés az egyén, a család és a társadalom szempontjából egyaránt, így érthető, hogy annak sikertelensége csalódást, kudarcot és frusztrációt jelent az érintettek számára. Különösen így van ez akkor, ha a fogantatás tartósan késik vagy egyáltalán nem valósul meg. Ha egy párnak szándéka ellenére nem születik gyermeke, és az erre irányuló vágyaik és erőfeszítéseik sorra eredménytelennek bizonyulnak, a meddőség megélése paranormatív krízist okozhat az érintett férfiak életében, mely depresszív és/vagy szorongásos tünetek megjelenésével, az önértékelés csökkenésével és a társas 
tér beszúkülésével járhat együtt. Negatívan befolyásolhatja a párkapcsolat minőségét, a munkaképességet, sőt kihathat a személy jövőképére, élete értelmének a megélésére is. E negatív lelkiállapotok külön-külön is jelentősen csökkenthetik a személy életminőségét és káros egészségmagatartások kialakulásához is vezethetnek (például dohányzás, túlzott mértékü alkoholfogyasztás) [29, 30]. A gyermekáldás érdekében vállalt erőfeszítések gyakorta hosszú időn át tartó, lelki és fizikai szempontból egyaránt megterhelő élethelyzetet teremtenek, amely felerősíti e negatív érzelmek intenzitását, továbbá kihívást jelent az énkép, az önbecsülés és a saját férfiasság/ nőiesség megélése szempontjából. Mindezek mellett a családalapításra vonatkozó társadalmi nyomás és a külső elvárások feszültségkeltő hatása sem hagyható figyelmen kívül [31]. A férfimeddőség kapcsán empirikusan legtöbbet kutatott kérdés az, hogy általában véve a stressz, illetve a fogantatás elmaradásából származó érzelmi feszültség miként hat a gyermeknemzés esélyeire. A stressz és az infertilitás összefüggését tekintve az alapvető kérdésfeltevés az, hogy vajon a stressz okozza-e a meddőséget, illetve hozzájárul-e annak kialakulásához, vagy a meddo"ség ténye és tudata okozza a stresszt, esetleg maga a meddőségi kezelés játszik szerepet stresszfaktorként. Egyre több a bizonyíték arra vonatkozóan, hogy a stressz fontos kockázati tényezőt jelent az infertilitás szempontjából. A meddőség emeli a distressz szintjét, ami az endokrin folyamatok, a szérumprolaktinszint emelkedése révén tovább rontja a fogantatás esélyeit [30].

A gyermek utáni vágy fokozódása olyan krízist jelent, amely lelki, fizikai és szociális hatással bír. A kivizsgálások és a meddőségi kezelések esetleges vállalása szintén jelentős mértékü megterhelést jelenthet az egyén és a pár számára egyaránt. Az asszisztált reprodukció kapcsán végzett kivizsgálás és kezelés során a lelki megterhelés fokozódik, a páciensek párkapcsolata 14\%-ban a terápia folyamán felbomlik [32].

A szakszerú pszichés vezetés egyre hangsúlyosabb szerepet tölt be a meddő párok ellátásában [33].

Ebben a fokozottan stresszkeltő élethelyzetben fontos az adaptív megküzdési (coping) stratégiák alkalmazása, amelyek során az egyén megpróbálja csökkenteni a stressz által okozott negatív hatásokat. Ilyen stresszfaktor lehet többek között a meddőség, a csökkent nemzőképesség, valamint az asszisztált reprodukciós kezelések vállalása. A megküzdésre számos stratégia létezik. Az egyik gyakran használt felosztás megkülönböztet problémaközpontú és érzelemközpontú megküzdést [34]. Az előbbi során az egyén megpróbálja megelőzni vagy megváltoztatni a fenyegetéseket, a stresszhelyzetet. Ha az egyén ezt a stratégiát követi, odafigyel az életmódjára, egészségesen étkezik, rendszeresen sportol, ezzel megpróbálja elkerülni a spermaparaméterek további romlását. Ugyanakkor az érzelemközpontú megközelítés esetében az egyén a helyzet okozta érzelmi reakciókat próbálja csökkenteni azáltal, hogy nem vesz tudomást a problémáról, elbagatellizálja azt, valamilyen pótcselek- vést végez, esetenként alkoholizálásba vagy más függöségbe menekül, ami a spermaparaméterek további romlását okozhatja. Az érzelemközpontú stratégia célja fékezni a negatív érzelmek elhatalmasodását, illetve a probléma megoldásának elhalasztása. Az érzelemközpontú kérődző stratégiát alkalmazó személy gyakran aggódik a jövő miatt, bánkódik, önsajnálatba merül, miközben semmit nem tesz a megoldás érdekében.

Felvetődhet a kérdés, hogy vajon a probléma- vagy az érzelemközpontú megküzdési stratégiák eredményesebbek-e a férfimeddőséggel való megküzdésben. A válasz függ a meddőségi kezelés szakaszaitól: egy újonnan diagnosztizált fertilitási probléma esetében más megküzdési mód lehet adaptív, és más a kezelés különböző szakaszaiban [35]. Az érzelemközpontú kérődző megküzdés az infertilitás diagnózisával való szembesülést követően adaptívnak mondható, mivel a veszteség feldolgozásához időre van szükség. Ez a stratégia alkalmas a keletkezett érzelmi feszültség csökkentésére, valamint időt ad a rendeződésre, majd ezt követően a beteg eredményesen képes alkalmazni a problémaközpontú megküzdési stratégiát. A férfiak esetében a tervezést, azaz a problémaközpontú megközelítést, valamint a problémától való távolságtartó stratégia használatát tartják a legeredményesebbnek $[35,36]$.

Az észak-amerikai infertilis párok körében a férfiaknak összességében gyengébb, alacsonyabb a megküzdési stratégiájuk. Hajlamosak megbirkózni a ténnyel azáltal, hogy a munkában és más tevékenységekben való részvételüket növelik, optimistábbak, problémamegoldóbbak, és kevésbé igénylik a szociális támogatást. A férfiak könynyebben állnak át a gyermek nélküli életmódra, mint partnereik, akiknek nehezebb megoldaniuk a meddőség problematikáját. A férfiassági normáknak megfelelően sok férj hajlamos elnyomni érzelmeit a felesége támogatása érdekében [36]. Ez a tendencia azzal is járhat, hogy a férfiaknál a meddőséggel összefüggő szorongás tényleges szintje alulértékelt.

A kutatási eredmények szerint a férfiaknak általában gondot okoz, hogy korlátozott lehetőségeket látnak a meddőségi probléma megoldására vagy akár arra, hogy abban a párjuknak segítséget nyújtsanak. Ez a tehetetlenség azután a saját hatékonyságuk érzésének csökkenéséhez és fokozott stresszhez vezet. Nem érzik magukat képesnek arra, hogy a problémát egyedül megoldják, nem tudják, pontosan mit tehetnének a megoldás érdekében. A szégyen, a büntudat, a haszontalanság érzése, a félelem és a kétségbeesés a felszín alatt erősödik a férfiban, amiért már nem ő az uralkodó a családalapítás mikéntje és időzítése felett $[30,37]$. A tervezés azért számít az adott élethelyzetben adaptív megküzdési módnak, mivel a probléma kezelésére vonatkozó stratégia felépítése, a célirányos cselekvések sorának megtervezése növeli a kontroll és a kompetencia érzését, és segít abban, hogy a pár közös erőfeszítéseket tegyen a helyzet megoldására [35].

A vizsgálatok eredményei szerint az infertilitás vonatkozásában az elkerülés - azaz elkerülni a meddőségre 
emlékeztető helyzeteket és személyeket -, valamint az önhibáztatás elégtelen megküzdési stratégiák. Mindkettő a stressz magas szintjével jár együtt, és a szorongásosdepressziós tünetek megjelenésének prediktív tényezői $[35,36]$.

\section{Paramedikális tanácsadás mint támogatási lehetőség a férfimeddőségben}

A kedvezőtlen egészségmagatartás megváltoztatását célzó intervenciók és programok hatékony elemei lehetnek a meddőség kezelésének. Ugyanakkor az is elmondható, hogy a lelki tényezók hatása a fertilitási problémák kialakulására és fennmaradására ma már nem vitatható. A gyermektelenség megélése sokszor kultúrától függetlenül hasonló jegyeket mutat; szégyen, bứntudat, a haszontalanság érzése, a bizonytalanság átélése és az önértékelés fenyegetettségének érzése [30,37].

$\mathrm{Az}$ infertilitás, illetve a társbetegségek megfelelő kezeléséhez, az esetleges szövődmények megelőzéséhez a betegeknek számos új ismeretet, készséget kell elsajátítaniuk. Mint társadalmunk modern betegei, a páciensek aktívan részt akarnak venni saját gyógyulásuk folyamatában, valamint az ezzel kapcsolatos döntésekben, és ehhez egyre több információt kérnek és várnak el az egészségügyi ellátóktól [38]. Az egészségügyi információ keresése általában a házas, középkorú nőkre jellemző [39]. A férfiak a meddőséggel kapcsolatos információkkal korlátozottan rendelkeznek, a tanácsokat, információkat szívesebben fogadják írásban, továbbá bizonyított, hogy meddőség esetén, valamint kisebbségi csoportokban motiváltabbak az információk megszerzésében [40].

Ha nemcsak információt szeretnénk adni, hanem valamilyen változás fontosságáról szeretnénk meggyőzni a pácienst, és egyúttal motiválni szeretnénk arra, hogy változtasson életmódján, akkor figyelembe kell vennünk a pszichés tényezóket, valamint a beteg már meglévő ismereteit.

Ezek az információk számos csatornán elérhetők, fóként az internet kínál könnyen hozzáférhető lehetőségeket. A megbízhatóság és a minőség azonban nem mindig biztosított. Általában az orvoshoz fordulás után keresnek a meddőségben szenvedő férfiak információkat mintegy segítségként a döntéshozatalban [41]. Ismereteiket leginkább online elérhető forrásokból szerzik, amelyeket elsősorban Google-keresésekkel és a közösségi médián keresztül (Facebook) érnek el [42].

A sikertelen gyermekvállalás során a férfiaknál is megjelenik a meddőségre adott specifikus szorongás, szomorúság. A patozoospermiával vagy azoospermiával diagnosztizált férfiak többnyire bánatot, szégyent, partnerükkel szemben búntudatot éreznek [37]. Ennek ellenére nem szívesen fordulnak mentálhigiénés szakemberhez vagy önsegítő csoportok felé [29]. Jelentősen jobb hatásfokú a személyre szabott betegoktatás, ha a személyes konzultációk során minden beteg az előzetes tudásának, múveltségének, aktuális szükségleteinek és pszichoszociális állapotának megfelelő formában jut hozzá az információhoz [43].

A meddőséget kiváltó kockázati tényező́k prevenciójában lényeges a megfelelő motivációk kialakítása annak érdekében, hogy a betegek képesek legyenek például a javasolt életmódbeli változtatásokat végrehajtani.

A tanácsadási stratégiák alkalmazásával lehetôvé válik az információk befogadása, új készségek fejlesztése, új szokások kialakítása $[44,45]$.

A tanácsadási stratégiák ahhoz nyújtanak segítséget, hogy a közvetíteni kívánt ismereteket az érintettek be tudják illeszteni saját szemléleti és tapasztalati rendszerükbe, valamint ahhoz, hogy a betegek és hozzátartozóik valós képet alkothassanak a jelen helyzetükről, amely igen gyakran túlzottan is közeli ahhoz, hogy a segító és gátló tényezőket, továbbá a rendelkezésre álló lehetőségeket reálisan felmérhessék [46].

Egy 2001. évi tanulmány a termékenységi szolgáltatásokat nyújtók számára összefoglaló iránymutatást ad a tanácsadásra és a pszichoszociális ellátásra vonatkozóan. A munka a személyközpontú ellátás és a tanácsadás, rutinszerű kezelések integrálására összpontosít, rámutatva néhány olyan speciális helyzetre, amely a tanácsadás szükségességét igényelheti (például a kezelés befejezése, szexuális problémák). A meddőségi klinikák megfelelő gyakorlata magában foglalja a holisztikus ellátást.

A klinikáknak, meddőségi centrumoknak készen kell állniuk arra, hogy figyelembe vegyék és kezeljék azokat a pszichoszociális kérdéseket, amelyekkel gyakorta szembesülnek azoknál a párokkal, akik igénybe veszik szolgáltatásaikat. A betegközpontú tanácsadás alapvető feladata annak biztosítása, hogy a betegek megértsék kezelésük választásának következményeit, elegendő érzelmi támogatást kapjanak, és egészséges módon megbirkózzanak a meddőség megtapasztalásának következményeivel.

A betegellátás holisztikusabb megközelítését alkalmazva az egészségügyi eredmények javulnak, növekszik a páciensek és az ellátóteam elégedettsége, csökkennek a negatív pszichoszociális reakciók, a betegek jobban megértik tapasztalataikat [47].

A férfiak érzelmi jóllétének felmérése, valamint nyomon követése a kezdeti értékeléskor és a kezelés folyamán hasznos lehet. A meddőségben az érzelmi szükségletek spontán feltárása és az explicit támogatáskeresés, úgy tünik, nem gyakori a férfiak között. Néhány kutató ezért javasolja a mentális egészség szisztematikus értékelését a pszichometriai kérdőívek és a kezelési protokollok segítségével. Megfogalmazódik továbbá egy olyan, első vonalbeli klinikai stratégia kialakításának szükségessége is, amely mentális egészségügyi szakemberek bevonásával potenciálisan csökkentheti a társadalmi elszigeteltséget és szorongást, valamint segíthet azoknak a férfiaknak az alcsoportjában, akik nem hozták nyilvánosságra helyzetüket házastársukon kívül bárkinek, akik reménytelennek vagy túl súlyosnak ítélik meg a helyzetüket [48]. Intervenciók és célzott programok szükségességét feltáró tanulmányok eredményei arra utalnak, hogy a meddő- 
ségi szolgáltatások körében végzett átfogó klinikai ellátás különös jelentőséggel bír az érzelmi jóllét védelmében az infertilitás által érintett férfiak körében. A férfiak egyre valószínúbben bíznak meg valakiben, vágynak információra és érzelmi támogatásra [49].

\section{Következtetés}

A fentiek alapján nyilvánvaló, hogy a férfimeddőség ellátásában kiemelt szerepet kell biztosítani a támogató terápiának, amelynek fókuszában az információ nyújtása mellett a kezelési időszakban keletkező hatások, tapasztalatok, ismeretek feldolgozásának támogatása, a streszszel való adaptív megküzdési stratégiák kialakítása, valamint a reproduktivitást befolyásoló egészségmagatartásváltozók közvetlen vagy közvetett módosítása kell, hogy álljon. Annak ellenére, hogy az orvoslás számtalan hatékony beavatkozási lehetőséggel rendelkezik az infertilitás leküzdéséhez, tapasztalható és gyakran nehezen értelmezhető az érintettek kezelésének „elakadása” vagy a személyek kilépése az ellátási folyamatból.

A betegek kilátásairól szóló kutatás szisztematikus vizsgálata azt mutatja, hogy nagyon kevés tanulmány összpontosít a férfiak termékenységi ellátása során megszerzett tapasztalatokra. A férfiak beszámolói alapján a releváns dimenziók az összes meddőségi szolgáltatást igénybe vevőkre vonatkoztak, és a következő paramétereket tartalmazták: a szolgáltatásokhoz való hozzáférés; értékek tisztelete; választások és igények; az ellátás folyamatossága és összehangolása; megfelelő tájékoztatás és oktatás; fizikai kényelem; szorongás csökkentése és a partnerek bevonása. A szerzők arra a következtetésre jutottak, hogy kevés bizonyíték áll rendelkezésre a férfiak gondozására vonatkozóan, különösen az invazív eljárásokat megelőző információnyújtás vagy akár a pszichés támogatás tekintetében [50].

Számos vizsgálat tárta fel azt a tényt is, hogy a meddőség megélése paranormatív krízist okozhat az érintett férfiak életében, amely depresszív és/vagy szorongásos tünetek megjelenésével, az önértékelés csökkenésével és a társas tér beszúkülésével járhat, amelyek mérsékléséhez a pszichológiai gondozás értékes támogatást nyújthat. A tényleges kezelési időszakban keletkező hatások, tapasztalatok, ismeretek feldolgozásának támogatására azonban igen kevés figyelem irányul. Gyakorlatilag hiányoznak azok a célzott intervenciók és programok, amelyek az ápolás területén segíthetnék az orvosi ellátás folyamatával összefüggő, a személy kontrollja alatt álló, többékevésbé módosítható életmódváltozókból eredő lehetőségek hasznosítását. Kiemelten figyelmet érdemel ezért az ápolói betegvezetés [51-53] és a paramedikális tanácsadás alkalmazásában rejlő lehetőségek feltárása a kezelési időszakban [54]. Az együttmúködésen alapuló gondozási folyamatban a professzionális ápolónak olyan kapcsolatot kell kialakítania, amelynek légköre kedvezően hat a beteg belső erőforrásainak mozgósítására, a kompetencia érzésének visszanyerésére saját sorsának irá- nyításában és a saját egészsége menedzselésében. Célunk az információ nyújtásán, azok feldolgozásának és a döntés kialakításának támogatásán túl a betegekben lévő erőforrások aktivizálása és összpontosításának segítése a keletkező hatások, tapasztalatok, ismeretek feldolgozásának elősegítése érdekében, amely tevékenység többek között a biztonságos betegellátás egyik meghatározó tényezőjeként is tekinthető.

Anyagi támogatás: A közlemény megírása anyagi támogatásban nem részesült.

Szerzői munkamegosztás: Sz. A.: Hipotézisek, vizsgálati kérdések kidolgozása, szakirodalmi másodelemzés, a kézirat szövegezése. F. Zs.: Szakirodalmi másodelemzés, a kézirat szövegezése. K. I.: A kézirat szövegezése. A cikk végleges változatát mindhárom szerző elolvasta és jóváhagyta.

Érdekeltségek: A szerzőknek nincsenek érdekeltségeik.

\section{Irodalom}

[1] A policy audit on fertility. Analysis of 9 EU countries 2017. Available from: http:// PolicyAuditonFertilityAnalysis9EUCountriesFINAL16032017-3.pdf [accessed: December 29, 2017].

[2] Kaáli NG, Bártfai Gy. Infertility of male origin. In: Pásztor N. (ed.) Modern diagnostics and treatment of infertility. [Férfi eredetû meddőség. In: Pásztor N. (ed.) A meddőség korszerü diagnosztikája és kezelése.] Medicina Könyvkiadó, Budapest, 2018; pp. 121-168. [Hungarian]

[3] Hungarian Central Statistical Office. Hungary 2014. [Központi Statisztikai Hivatal. Magyarország 2014.] Available from: https://www.ksh.hu/docs/hun/xftp/idoszaki/mo/mo2014.pdf [accessed: December 30, 2017]. [Hungarian]

[4] Jungwirth A, Diemer T, Dohle GR, et al. Guidelines on male infertility. European Association of Urology, 2015. The 2017 update. [accessed: December 30, 2017].

[5] Kahyaoglu Sut H, Balkanli Kaplan P. Quality of life in women with infertility via the FertiQoL and the Hospital Anxiety and Depression Scales. Nurs Health Sci. 2015; 17: 84-89.

[6] Chiaffarino F, Baldini MP, Scarduelli C, et al. Prevalence and incidence of depressive and anxious symptoms in couples undergoing assisted reproductive treatment in an Italian infertility department. Eur J Obstet Gynecol Reprod Biol. 2011; 158: 235-241.

[7] Cserepes RE, Körösi T, Bugán A, et al. Characteristics of infertility specific quality of life in Hungarian couples. [A meddőséggel összefüggő életminőség jellemzői magyar pároknál.] Orv Hetil. 2014; 155: 783-788. [Hungarian]

[8] El Kissi Y, Romdhane AB, Hidar S, et al. General psychopathology, anxiety, depression and self-esteem in couples undergoing infertility treatment: a comparative study betwen men and women. Eur J Obstet Gynecol Reprod Biol. 2013; 167: 185-189.

[9] Lakatos E, Pápay N, Ádám Sz, et al. Paradigms in infertility interpretation. [Paradigmák a meddőség értelmezésében.] Pszichológia 2014; 34: 261-287. [Hungarian]

[10] Lőrincz J, Jakab A, Török P. Comparison of current methods of tubal patency assessment. [A petevezeték-átjárhatóság vizsgálómódszereinek összehasonlító elemzése.] Orv Hetil. 2017; 158: 324-330. [Hungarian]

[11] Schill WB, Comhaire FH, Hargreave TB. Oligo-astheno-teratozoospermia with no demonstrable cause. In: Comhaire F, Mahmoud A. (eds.) Andrology for the clinician. Springer-Verlag, Berlin, 2006; pp. 77-84. 
[12] Sápy T, Póka R. Oncofertility and therapeutic modalities. Survey of literature. [Onkofertilitás és kezelési lehetôségei. Irodalmi áttekintés.] Orv Hetil. 2017; 158: 683-691. [Hungarian]

[13] Szigeti FJ, Ács N. Biopsychosocially informed therapy of symptoms related to premature ovarian failure. [Korai petefészekkimerüléssel összefüggő tünetek bio-pszicho-szociális szemléletű kezelése.] Orv Hetil. 2017; 158: 1432-1435. [Hungarian]

[14] Wichman CL, Ehlers SL, Wichman SE, et al. Comparison of multiple psychological distress measures between men and women preparing for in vitro fertilization. Fertil Steril. 2011; 95: 717-721.

[15] Throsby K, Gill R. It's different for men: masculinity and IVF. Men Masculinities 2004; 6: 330-348.

[16] Dudgeon MR, Inhorn MC. Gender, masculinity and reproduction: anthropological perspectives. Int J Men's Health 2003; 2 : $31-56$.

[17] Kopp M, Skrabski Á. Health status of women and men in Hungary. In: Nagy I, Pongrácz T. (eds.) Changing roles. Report on the situation of women and men. [Nók és férfiak egészségi állapota Magyarországon. In: Nagy I, Pongrácz T. (szerk.) Szerepváltozások. Jelentés a nők és férfiak helyzetérốl.] TÁRKI, Budapest, 2009; pp. 117-136. [Hungarian]

[18] Gurunath S, Paudian Z, Anderson RA, et al. Defining infertility - a systematic review of prevalence studies. Hum Reprod Update 2011; 17: 575-588.

[19] Bacon, CG, Mittleman MA, Kawachi I, et al. Prospective study of risk factors for erectile dysfunction. J Urol. 2006; 176: 217 221.

[20] Du Plessis SS, Cabler S, McAlister DA, et al. The effect of obesity on sperm disorders and male infertility. Nat Rev Urol. 2010; 7: 153-161

[21] Kort HI, Massey JB, Elsner CW, et al. Impact of body mass index values on sperm quantity and quality. J Androl. 2006; 27: 450452 .

[22] Sallmén M, Sandler DP, Hoppin JA, et al. Reduced fertility among overweight and obese men. Epidemiology 2006; 17: 520-523.

[23] Håkonsen LB, Thulstrup AM, Aggerholm AS, et al. Does weight loss improve semen quality and reproductive hormones? Results from a cohort of severely obese men. Reprod Health 2011; 8: 24 .

[24] Li Y, Lin H, Li Y, et al. Association between socio-psycho-behavioral factors and male semen quality: systematic review and metaanalyses. Fertil Steril. 2011; 95: 116-123.

[25] Olayaki LA, Edeoja EO, Jimoh OR, et al. Effect of cigarette smoking on urinary testosterone excretion in men. Biokemistri 2008; 20: 29-32.

[26] Waylen AL, Metwally M, Jones GL, et al. Effects of cigarette smoking upon clinical outcomes of assisted reproduction: a meta-analysis. Hum Reprod Update 2009; 15: 31-44.

[27] Wise LA, Cramer DW, Hornstein MD, et al. Physical activity and semen quality among men attending an infertility clinic. Fertil Steril. 2011; 95: 1025-1030.

[28] Wogatzky J, Wirleitner B, Stecher A, et al. The combination matters - distinct impact of lifestyle factors on sperm quality: a study on semen analysis of 1683 patients according to MSOME criteria. Reprod Biol Endocrinol. 2012; 10: 115

[29] Fisher JR, Hammarberg K. Psychological and social aspects of infertility in men: an overview of the evidence and implications for psychologically informed clinical care and future research. Asian J Androl. 2012; 14: 121-129.

[30] Greil AL, Slauson-Blevins K, McQuillan J. The experience of infertility: a review of recent literature. Soc Health Illn. 2010; 32: 140-162.

[31] Schneid-Kofman N, Sheiner E. Does stress effect male infertility? - A debate. Med Sci Monit. 2005; 11: SRl1-SRl3.

[32] Martins MV, Costa P, Peterson BD, et al. Marital stability and repartnering: infertility-related stress trajectories of unsuccessful fertility treatment. Fertil Steril. 2014; 102: 1716-1722.

[33] Hakim LZ, Newton CR, MacLean-Brine D, et al. Evaluation of preparatory psychosocial counselling for medically assisted reproduction. Hum Reprod. 2012; 27: 2058-2066.
[34] Skinner EA, Edge K, Altman J, et al. Searching for the structure of coping: a review and critique of category systems for classifying ways of coping. Psychol Bull. 2003; 129: 216-269.

[35] Peterson BD, Newton CR, Rosen KH, et al. Gender differences in how men and women who are referred for IVF cope with infertility stress. Hum Reprod. 2006; 21: 2443-2449.

[36] Faramarzi M, Pasha, H, Esmaelzadeh, S, et al. Is coping strategies predictor of anxiety and depression in couple infertile? Health 2013; 5: 643-649.

[37] Swierkowski-Blanchard N, Alter L, Salama S, et al. To be or not to be [fertile], that is the question. Basic Clin Androl. 2016; 26: 12.

[38] Kapcsi E. "Unhappy doctors" - the phenomenon and what's behind it. ["Boldogtalan orvosok” - a jelenség és ami mögötte van.] LAM 2011; 21: 584-588. [Hungarian]

[39] Clyde JW, Domenech Rodríguez MM, Geiser C. Medical professionalism: an experimental look at physicians' Facebook profiles. Med Educ Online 2014; 19: 23149.

[40] Daumler D, Chan P, Lo KC, et al. Men's knowledge of their own fertility: a population-based survey examining the awareness of factors that are associated with male infertility. Hum Reprod. 2016; 31: 2781-2790.

[41] Baunacke M, Groeben C, Borgmann H, et al. Andrology on the internet: Most wanted, controversial and often primary source of information for patients. Andrologia 2018; 50: el2877.

[42] Borgmann H, Kliesch S, Roth S, et al. Feasibility and efficacy of a urologic profession campaign on cryptorchidism using internet and social media. Urol Int. 2017; 98: 478-482.

[43] Roter DL, Hall JA. Physician gender and patient-centered communication: a critical review of empirical research. Annu Rev Public Health 2004; 25: 497-519.

[44] Johnson BM, Webber PB. Nursing theory. In: Johnson BM, Webber PB. An introduction to theory and reasoning in nursing. 4th ed. Lippincott, Williams and Wilkins, 2015; pp. 130-195.

[45] Kitto S, Goldman J, Etchells E, et al. Quality improvement, patient safety, and continuing education: a qualitative study of the current boundaries and opportunities for collaboration between these domains. Acad Med. 2015; 90: 240-245.

[46] Legare F, Ratte S, Gravel K, et al. Barriers and facilitators to implementing shared decision-making in clinical practice: update of a systematic review of health professionals' perceptions. Patient Educ Couns. 2008; 73: 526-535.

[47] Boivin J, Appleton TC, Baetens P, et al. Guidelines for counselling in infertility. Hum Reprod. 2001; 16: 1301-1304.

[48] Brucker PS, McKenry PC. Support from health care providers and the psychological adjustment of individuals experiencing infertility. J Obstet Gynecol Neonatal Nurs. 2004; 33: 597-603.

[49] Hammarberg K, Baker HW, Fisher JR. Men's experiences of infertility and infertility treatment $\mathbf{5}$ years after diagnosis male factor infertility: a retrospective cohort study. Hum Reprod. 2010; 25: 2815-2820.

[50] Dancet EA, Nelen WL, Sermeus W, et al. The patients' perspective on fertility care: a systematic review. Hum Reprod Update 2010; 16: 467-487.

[51] Helembai K. General nursing psychology. In: Helembai K. (ed.) Psychology of patient/client guidance. [Általános ápoláslélektan. In: Helembai K. (szerk.) A beteg/kliensvezetés pszichológiája.] Medicina Könyvkiadó, Budapest, 2012; pp. 136-192. [Hungarian]

[52] Helembai K. Fraiming the concept of patient/client conducting. Acta Sana 2014; 9: 18-23.

[53] Helembai K. Aspects of patient conducting in nursing. Acta Sana 2015; 1: 23-29.

[54] Papp L, Nagy E, Erdősi E, et al. The importance of nursing and patient interactions in patient care. [Az ápoló-beteg interakciók jelentősége a betegellátásban.] IME Interdiszciplináris Magyar Egészségügy 2009; 8: 38-41. [Hungarian]

(Szatmári Angelika, Szeged, Temesvári krt. 31., 6726 e-mail: szatmari@etszk.u-szeged.hu) 